\title{
The Andersen-Jordan Approach after Nearly 20 Years
}

\author{
Jerry L. Jordan
}

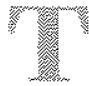
essential propostions were first put forth in an article in the July 1968 Review of the Federal Reserve Bank of St. Louis entitled "The Role of Money in Monetary Policy" by Karl Brunner. In it, Brunner states that,

\begin{abstract}
The critique of established policy procedures, which evolved from this research into questions conceming the monetary mechanism, is derived from a body of monetary theory referred to ... as the Monetarist position [emphasis added]. Three major conchusions have emerged from the hypotheses put forth. First, mone tary impulses are a major factor accounting for variations in output, employment and prices. Second, movements in the money stock are the most reliable measure of the thrust of monetary impulses. Third, the behavior of the monetary atuhority dominates movements of the money stock over business cycles.
\end{abstract}

The process of defining and refining what we now mean by monetarism grew out of a controversy that emerged in the 1960 s regarding the relative importance of monetary and fiscal impulses. The dominant economic policy framework of the day was an outgrowth of the thinking of the 1930s, which became known as Keynesianism. The rapid growth of government spending associated with the Vietnam War, the Great Society programs and relatively large deficits in the federal government's budget were associated with conditions of rapid economic growth, rising inflation and a low unemployment rate. The political prescription for the problem of inflation was a surtax on personal and corporate incomes to restrain aggregate demand and reduce inflation.

Jerry L. Jordan is a senior vice president and chief economist at First interstate Bancorp, Los Angeles, California, and a former director of research at the Federal Reserve Bank of St. Louis.
Adherents to the propositions that became known as monetarism questioned whether such fiscal actions would, in fact, restrain aggregate demand and reduce inflation if monetary growth remained as rapid as it had been previously, Since the dominant position of the time was known as the Keynesian revolution, the critics of that view were said to have mounted a monetarist counterrevolution. At times, the quality of the discussion was sily, including such insights as "you can pull on a string, but you can't push on a string" and "you can lead a horse to water, but you can't make him drink." At other and more useful times, state-of-the-art econometric techniques were used to test rival conjectures about monetary and fiscal impulses.

The skirmishes of the period included the Friedman-Heller debate, the "Battle of the Radio Stations" - which referred to the research done by Ando-Modigliani (AM) and Friedman-Meiselman (FM) - and the associated contributions by DePrano, Hester and Mayer and by Brunner and Meltzer. The role of what became known as the gadfly or maverick research department of the Fedeal heserve Bank of St. Louis is now well-known in economics circles; although it had started a few years earlier, it was given greatly heightened visibility with the publication of the Andersen-Jordan (AJ) article in 1968.

The 1966 credit crunch and subsequent "minirecession" had demonstuated the potential for a restrictive monetary policy, measured in terms of a deceleration of monetary growth, to dominate an expansive fiscal impulse. In 1968, the issue was whether monetary stimulus - as indicated by contin ued rapid growth of money - could dominate a restrictive fiscal impulse as measured by a tax increase, reduction in the high employment deficit or 
some other summary variable. The research underlying the AJ article was motivated by two events: the Johnson administration's anti-inflation surcharge on personal and corporate income tax and the foMC's decision to ease monetary policy to cushion the presumed highly restrictive effects of the tax surcharge.

We considered the $\mathrm{AJ}$ article to be a sequel to the FM article. Our purpose was to rigorously formulate potentially falsifiable hypotheses about various macroeconomic policy actions. The article also was an exercise in applying what was then state-of-the-art computerized regression programs using the Almon distributed lag for testing hypotheses.

I believe that the vehemence of the attacks on the AI article arose from two sources. First, the results of the study sharply contradicted the inherited wisdom of the times and raised serious doubts about our ability to use activist/discretionary fiscal policy to influence the economy in predictable ways.

A second reason for the attacks was simply that the reduced-form approach used in the AJ study represented a threat to econometric model builders; it provided a low-cost alternative to the expensive efforts at the time to build large-scale structural models of the U.S economy. For example, around that time, the Federal Reserve Board had entered into a contract to spend about $\$ 1$ million to build what became known as the FRB-MIT econometric model. In my judgment, the structural model-builders of the times simply could not afford to leave unchallenged the competition that this relatively cheap approach presented in evaluating policy effects on the economy. In any event, those threatened by its challenge both to economic orthodoxy and to the usefulness of large-scale models had great incentive to seek to discredit the AJ methodology.

Thus, as the decade of the 1960 s ended, the lines had been drawn for a prolonged intellectual battle. The Keynesian revolution was still dominant, but the challenge of the monetarist counterrevolution had been initiated. The 1970 s was a decade of formulation, reformulation and empirical testing of the atternative views of the major macroeconomic influences on the economy. By the end of the 1970s and into the early 1980s, further testing of monetarist propositions by actual implementation was attempted, at least in name, if not in fact.

Recently, there have been numerous claims that monetarism has failed. Certainly the case against monetarism has been tried in the press with journalists acting as both prosecutors and jury. Economists, however, have yet to complete their deliberations. Because the "breakdown" of the AJ results is often cited as evidence against monetarism, I would like to comment briefly on the current controversy.

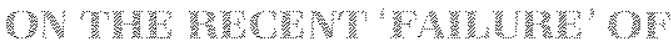

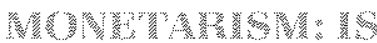 "ANDHWSEW-GOWVAN" PASSE?}

The failure of monetarism has been asserted and reasserted often during the past few years. This failure is based on the contention that the relationship between money growth and GNP, or money growth and inflation, has broken down. In particular, the behavior of the income velocity of money over the last few years, especially in 1985, has raised questions about one of the central propositions of the quantity theory of money, or monetarism - namely, the stability of the demand function for money. The sharp decreases and increases in conventionally measured velocity have led to assertions that the demand for money is unstable and, therefore, the money supply (M1) is no longer a reliable indicator of the thrust of monetary policy impulses.

Growth rates of M1 over short intervals during the last few years have been highly volatile, and the contemporaneously measured ratio of GNP/M1 also has fluctuated over a wide range. Unfortunately, both monetarists and their critics seem to accept the view that the public policy relevance of monetarism depends on the short-run stability of the functional relationship between domestic income and/or output and growth of the money supply. The short-run volatility of a data series such as the ratio GNP/M1, however, does not yield any definitive information about the stability of the underlying functional relationship between money and economic activity.

There are three important aspects of velocity behaviof in the recent past that must be examined: the role of institutional changes, the implications of lags and the appropriateness of the numerator in computing the velocity ratio.

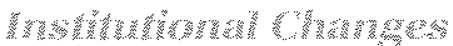

Some analysts assert that deregulation of the financial system, starting with the Depository Institutions Deregulation and Monetary Control Act of 1980 and continued with the Garn-St. Germain legislation in 1982, has altered the behavior of M1 and, in turn, has caused the volatile behavior of velocity in the last two years. The empirical issue, on which there is no con- 
sensus at this time, is the degree to which the "demand for money balances" has shifted upward relative to income or wealth and, consequently, a downward shift in at least the level, and possibly the trend growth rate, of M1 velocity.

It has been argued that the removal of Regulation $Q$ interest ceilings on bank deposits and the innovation of new types of deposit instruments has resulted in M1 containing a large savings component. Therefore, faster growth of the money supply, such as what occurred in 1985-86, should not be taken as an indicator of as much stimulus as before since the demand for money balances is also rising. Without an excess supply condition, it is argued, there is no reason to expect nominal income growth to accelerate.

Monetarists generally accept the view that deregulation and financial innovation have most likely resulted in a reduction in the trend rate of growth of M1 velocity. There is no reason, however, to believe that the level of velocity would be expected to decline. The trend rate of increase of historic $\mathrm{M} 2$ velocity has been between 0 and 1 percent. M2 has always contained a relatively large savings component. Deregulation and innovation may have resulted in M1 taking on the characteristics of historic M2. At this point, however, we do not have sufficient evidence to draw firm conclusions.

Even if M1 is now like old M2, the trend rate of increase of $M 1$ velocity would have declined from the 3 percent rate of the post-war period to something more similar to historic $\mathrm{M} 2$ velocity growth. There is no theotetical reason and no evidence to suggest that the trend of $\mathrm{M} 1$ velocity would be negative as a result of deregulation and innovation.

\section{7.}

The existence of lags in an environment of highly volatile short-run money growth must produce a highly volatile data series for velocity. Volatility of the data series, however, does not yield useful information about the stability of the underlying functional relationship.

This point can be illustrated with a simple example. Suppose it were known with cetainty that the lag between changes in money and changes in nominal income was exactly 180 clays. Suppose further that the growth of M1 accelerated and decelerated sharply over intervals lasting exactly six months. Starting from any initial condition, a sharp acceleration in M1 growth for six months would not be matched by an acceleation in the growth of the numerator of the velocity ratio, Consequently, contemporaneously measured velocity (V) would decine during the interval.

At the end of six months, the numerator would begin to rise more rapidly, while the denominator decelerated, causing a sharp increase in the V-ratio. Six months later, once again the denominator would accelerate while the numerator decelerated, causing a plunge in the V-fatio. Observing the behavior of the $\mathrm{V}$ ratio over several such cycles could easily lead an undergraduate money-and-banking student to conclude that velocity, or the demand for money, was not stable. It was a perfectly stable and predictable functional relationship, however, that produced the volatility of the data series.

The relevance of the point is that, over the last several years, we have observed increasingly sharp accelerations and decelerations of $\mathrm{M} 1$ growth, with each movement in the rate of change tending to last two to three quarters followed by a sharp reversal. Since the real-world lag is not discrete, but rather is distributed and variable, the challenge to empirical research is to develop techniques to identify the actual lag structure.

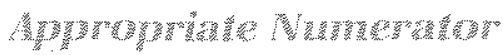

It is common practice to compute the velocity of money as the ratio of GNP divided by M1 or a broader money measure. The original quantity theory equation, however, was MV $=P T$, where $T$ is transactions. Changes in GNP reflect primarily changes in domestic output at prevailing prices, not total transactions at prevailing prices. The use of GNP in the velocity ratio implies both a closed economy and the stability of such components as business irventories. Since those assumptions are not a good representation of the real world, the use of GNP for computing velocity causes several problems.

In casual conversation, it is common to refer to GNP as a measure of aggregate demand of fotal spending in the economy. It is not. A rigorous formulation of the quantity theory of money, or monetarism, involves a statement about the demand for money balances relative to wealth or permanent income. Since quarterly fluctuations in GNP as compiled by the Commerce Department afe not a good proxy for changes in wealth or permanent income, the use of GNP to compute the inverse of the demand for money - velocity - causes significant measurement problems.

The theory implies that an acceleration in monetary growth results in increased spending growth. In a 
closed economy, a short-run manifestation of the increased spending would be an involuntary and unanticipated reduction in business inventories, increased ordering and increased production. 'The longer-term effect is a reduction in the purchasing power of nominal money units - inflation.

In an open economy, an increase in money growth may be accompanied by an increase in demand for imported goods as well as domestically produced output. A sharp and sustained acceleration of money growth that is accompanied by a large increase in imports suggests a decline in the GNP/M1 ratio, at least for a while. Other adjustments, however, gradually do take place - such as in the foreign exchange value of the domestic currency which changes the relative prices of internationally traded output; eventually more costly imports and more competitive exports will reverse the situation. Those lags can be very long and are difficult to predict, introducing further uncertainty into the relation befween money and GNP growth. This phenomenon limits the usefulness of monetarism in conducting short-run-oriented discretionary policies since the usefulness of money growth as an indicator of the thrust of monetary policy is usually gauged in terms of its reliability in forecasting GNP growth.

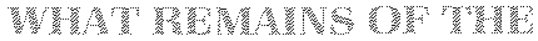

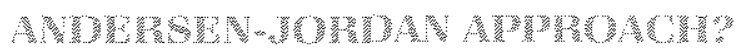

One central monetarist proposition has always been that activist, discretionary policies are neither necessary nor desirable. Therefore, if is ironic that the "St. Louis equation" unintentionally strengthened the views of the public policymakers who wanted to "manage" monetary policy to achieve different economic results. The empirical relation between money growth and nominal income was used as a rationalization for an activist, discretionary policy under which faster or slower target growth rates for money were adopted to achieve faster or slower growth rates of nominal GNP and, in tum, more or less inflation, output and employment.
The use of the St. Louis equation to engage in "finetuning" was neither intended nor anticipated by us. As I noted earlies, our intent was to demonstrate that expansive monetary fine-tuning, intended to offset a presumed contractionary fiscal impact, was neither necessary nor desirable. Much to our surprise and chagrin, our results were used by some to demonstrate the efficacy of monetary fine-tuning.

The basic problem with activist policies is that numerous factors affect economic performance; in the past two decades, there have been ample opportunities to accumulate data about the effects of both policy and non-policy developments on economic activity Yet, very little, if anything, has been learned from all this accumulated experience. The lags in the effects of policy actions are just as variable and just as uncertain, and policy actions still account for less than half the variability of economic variables.

The appendix to the Andersen-Jordan article emphasizes the importance of the " $Z$-factor," a variable summarizing all the other forces that influence total spending in the economy. While the text of the article concluded that monetary policy actions were relatively more important than fiscal actions, the analysis in the appendix suggests that a more complete conclusion would have been "and non-policy factors are even more important." The article's impact on economic policymaking would have been more favorable had it not led to an increased reliance on monetary over fiscal policy, but had it instead contributed to a general de-emphasis of fine-tuning attempts by policymakers. Some of the frustration and disappointment expressed by monetary policymaker's in recent years may have resulted from the unsatisfactory results they observed from this misuse of the theory.

In my judgment, the enduring contribution of the Af approach is the methodology employed to assess the differential impacts of policy actions on the economy, not the specific results offered at the time. While institutional and technological changes over time may alter empirical results, students of public policy debates can still usefully apply today the singleequation, reduced-form approach used by the AJ study 18 years ago. 